Article

\title{
Design Strategies for High Power vs. High Energy Lithium Ion Cells
}

\author{
Michael J. Lain ${ }^{1, *}$, James Brandon ${ }^{1}$ and Emma Kendrick ${ }^{1,2}$ (D) \\ 1 Warwick Manufacturing Group, University of Warwick, Coventry CV4 7AL, UK; \\ james.brandon@warwick.ac.uk (J.B.); E.Kendrick@bham.ac.uk (E.K.) \\ 2 School of Metallurgy and Materials, University of Birmingham, Birmingham B15 2TT, UK \\ * Correspondence: m.j.lain@warwick.ac.uk
}

Received: 8 August 2019; Accepted: 23 September 2019; Published: 5 October 2019

\begin{abstract}
Commercial lithium ion cells are now optimised for either high energy density or high power density. There is a trade off in cell design between the power and energy requirements. A tear down protocol has been developed, to investigate the internal components and cell engineering of nine cylindrical cells, with different power-energy ratios. The cells designed for high power applications used smaller particles of the active material in both the anodes and the cathodes. The cathodes for high power cells had higher porosities, but a similar trend was not observed for the anodes. In terms of cell design, the coat weights and areal capacities were lower for high power cells. The tag arrangements were the same in eight out of nine cells, with tags at each end of the anode, and one tag on the cathode. The thicknesses of the current collectors and separators were based on the best (thinnest) materials available when the cells were designed, rather than materials optimised for power or energy. To obtain high power, the resistance of each component is reduced as low as possible, and the lithium ion diffusion path lengths are minimised. This information illustrates the significant evolution of materials and components in lithium ion cells in recent years, and gives insight into designing higher power cells in the future.
\end{abstract}

Keywords: commercial lithium ion cells; power density; tear down; power vs. energy; electrode design; materials design

\section{Introduction}

In the years since lithium ion batteries (LIB) were introduced, there have been many developments in cell design and cell chemistry. For example, the volumetric energy density has doubled, through a combination of improved active materials and better cell engineering. With the increasingly widespread use of LIB for new applications, the cells have been optimised for energy (portable electronic devices, mobile phones and battery electric vehicles), or power (power tools, hybrid electric vehicles). For both the cell design and the active materials, there is a trade-off between power and energy. Different manufacturers use different approaches to optimise their cells for high energy density or high power density. This is typically know-how to the manufacturers. The majority of academic investigation in the area of high power lithium ion cells relate to active material design, rather than the equally important aspects of cell design and cell engineering. The relative performance of lithium ion batteries and ultra-capacitors have been compared previously [1-3]. In this work, most of the cells investigated were cylindrical 18650 cells, because they are available with different power-energy ratios, from the same manufacturer. This enabled different design approaches and strategies to be compared.

When designing a lithium ion cell, there are a series of design decisions, as summarised in Table 1 . The electrode compositions, coat weights, porosities, the current collectors, the separator, the electrolyte and the connection tags are all optimised, to obtain the required cell safety and performance 
properties. The active materials dictate the choice of binder and type of conductive carbon. Subsequent decisions are around the electrode loading, thickness and porosity. In earlier studies, the influence of electrode coat weight on rate performance and cell resistance have been modelled [4] and measured [5]. Experimentally, better rate performance was obtained with thinner electrodes.

Table 1. Design parameters used to optimise lithium ion cells.

\begin{tabular}{|c|c|c|}
\hline Component & Energy Density & Power Density \\
\hline Electrodes & $\begin{array}{l}\text { High coat weights } \\
\text { Low coating porosity } \\
\text { Medium + large particle sizes } \\
\text { Low conductive carbon content } \\
\text { Minimum possible binder content }\end{array}$ & $\begin{array}{l}\text { Low coat weights } \\
\text { High coating porosity } \\
\text { Small + medium particle sizes } \\
\text { High conductive carbon content }\end{array}$ \\
\hline Current collectors & $\begin{array}{c}\text { Thinner } \\
\text { Coated to improve adhesion }\end{array}$ & $\begin{array}{c}\text { Thicker } \\
\text { Coated to reduce resistance }\end{array}$ \\
\hline Separator & Thin & Thin \\
\hline Electrolyte & High conductivity & High conductivity \\
\hline Connection tags & $\begin{array}{c}\text { Thin/narrow tags } \\
\text { Single tag on each electrode }\end{array}$ & $\begin{array}{l}\text { Thick/wide tags } \\
\text { Multiple tags }\end{array}$ \\
\hline
\end{tabular}

Typically, the requirements for maximum energy density are opposite from those for high power density, a classic engineering trade off. However, the separator thickness is generally specified based on safety or manufacturability. Assuming that the cell is using a liquid electrolyte, there are some choices available in terms of the lithium salt and concentration, the organic carbonate solvent mixture, and the additives. The electrolyte composition will depend on the target operating temperature range of the cells, and the additives will be selected to improve the performance of specific active materials.

As indicated above, this paper describes the disassembly or teardown of commercial lithium ion cells, and the characterisation of their components. This includes physical properties of the electrodes, particularly the areal capacities and porosities, and other cell design parameters.

\section{Results}

The cells selected for this study are listed in Table 2. Most of the cells were procured via online retailers servicing the e-cigarette or vaping community. The A123 cells were purchased from a Chinese on line retailer. The rated capacity and maximum continuous discharge power values were taken from the data sheets, along with the design date. It should be noted that the original design dates were several years before the cells were actually purchased. This shows that it can take months or years of development work to proceed from an initial design specification to a cell available in the market place. The power-energy ratios are shown as $\mathrm{W}: \mathrm{W} \mathrm{hr}$, although they were calculated from a current (A) and a capacity (A hr).

Table 2. Lithium ion cells included in this study.

\begin{tabular}{ccccccc}
\hline Manufacturer & Model & Size & $\begin{array}{c}\text { Rated } \\
\text { Capacity/A hr }\end{array}$ & $\begin{array}{c}\text { Disch. } \\
\text { Current/A }\end{array}$ & $\begin{array}{c}\text { Power:Energy/ } \\
\text { W:W hr }\end{array}$ & Design Date \\
\hline A123 & M1A & 18650 & 1.1 & 30 & 27.3 & $2009[6]$ \\
LG & HB2 & 18650 & 1.5 & 30 & 20.0 & $2011[7]$ \\
LG & HB4 & 18650 & 1.5 & 30 & 20.0 & $2011[8]$ \\
LG & HG2 & 18650 & 3.0 & 20 & 6.7 & $2014[9]$ \\
Samsung & 25R & 18650 & 2.5 & 20 & 8.0 & $2013[10]$ \\
Samsung & 30Q & 18650 & 3.0 & 15 & 5.0 & $2014[11]$ \\
Samsung & 48G & 21700 & 4.8 & 10 & 2.1 & $2015[12]$ \\
Sony & VTC5A & 18650 & 2.5 & 30 & 12.0 & $2015[13]$ \\
Sony & VTC6 & 18650 & 3.0 & 20 & 6.7 & $2015[14]$ \\
\hline
\end{tabular}


The cells were received with an initial state of charge (SoC) of 20-40\%. It is safer to disassemble a fully discharged cell, and therefore a discharge-charge-discharge cycle was performed. The voltage profiles are shown in Figure 1. Eight of the cells had voltage profiles typical of layered cathode materials such as NMC $\left(\mathrm{LiNi}_{x} \mathrm{Mn}_{\mathrm{y}} \mathrm{Co}_{1-x-y} \mathrm{O}_{2}\right)$ and NCA $\left(\mathrm{LiNi}_{\mathrm{x}} \mathrm{Co}_{\mathrm{y}} \mathrm{Al}_{1-\mathrm{x}-\mathrm{y}} \mathrm{O}_{2}\right)$. The exception was the $\mathrm{A} 123$ M1A cell, which is known to have an LFP (lithium iron phosphate, $\mathrm{LiFePO}_{4}$ ) cathode. All the cells exceeded their rated capacity slightly, except the A123 M1A cell. Based on information supplied with the cells, the M1A cells were three years old on receipt, so that calendar ageing may have occurred. Storage at $40 \% \mathrm{SoC}$ at an unknown temperature for three years is likely to cause some loss of capacity. The discharge capacities and energies recorded during this cycle are collected in Table 3.

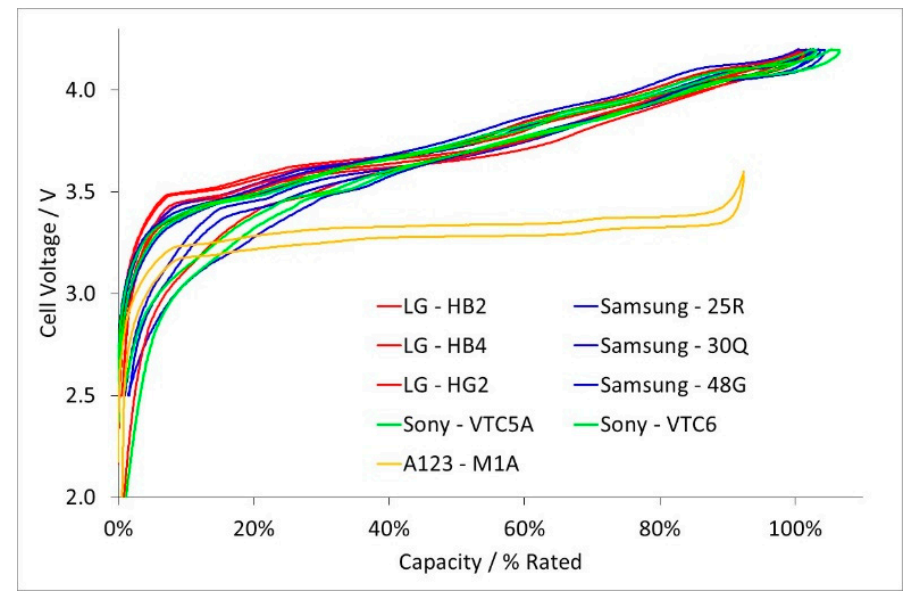

Figure 1. Cell voltages during initial capacity check.

Table 3. Properties measured during capacity check.

\begin{tabular}{ccccc}
\hline Manufacturer & Model & Size & $\begin{array}{c}\text { Discharge } \\
\text { Capacity/A hr }\end{array}$ & $\begin{array}{c}\text { Discharge } \\
\text { Energy/W hr }\end{array}$ \\
\hline A123 & M1A & 18650 & 1.011 & 3.28 \\
LG & HB2 & 18650 & 1.526 & 5.65 \\
LG & HB4 & 18650 & 1.535 & 5.71 \\
LG & HG2 & 18650 & 3.021 & 11.01 \\
Samsung & 25R & 18650 & 2.569 & 9.46 \\
Samsung & 30Q & 18650 & 3.089 & 11.23 \\
Samsung & 48G & 21700 & 4.838 & 17.76 \\
Sony & VTC5A & 18650 & 2.560 & 9.36 \\
Sony & VTC6 & 18650 & 3.163 & 11.52 \\
\hline
\end{tabular}

The measured discharge energy values were combined with the cell weights and volumes, to calculate two energy density values, as shown in Table 4 . The table also includes volumetric and gravimetric power density values. The power density can be measured or calculated in various ways. In this case, the power was defined as the average discharge voltage multiplied by the maximum continuous discharge current. In practice, the cell voltage during a high rate discharge will be lower than the average discharge voltage. However, the maximum pulse discharge current is higher than the maximum continuous current, because there is no risk of the cell over-heating. Table 4 also contains the total area of the cathodes, obtained by direct measurements of the actual electrodes. These were combined with the cell capacities to give values for the areal capacities. When designing cells, and balancing the anode and cathode capacities, this is one of the initial values that are specified. In Figure 2, the power-energy ratios of the cells are plotted against the areal capacities. As expected, there was an inverse relationship between these two parameters i.e., high power cells use low areal capacities and low coat weights. 
Table 4. Measured and calculated properties of cells.

\begin{tabular}{|c|c|c|c|c|c|c|c|c|}
\hline \multirow{2}{*}{ Manufacturer } & \multirow{2}{*}{ Model } & \multirow{2}{*}{$\begin{array}{l}\text { Weight } \\
\text { /g }\end{array}$} & \multirow{2}{*}{$\begin{array}{l}\text { Volume } \\
/ \mathrm{cm}^{3}\end{array}$} & \multirow{2}{*}{$\begin{array}{l}\text { Cathode } \\
/ \mathrm{cm}^{2}\end{array}$} & \multicolumn{2}{|c|}{ Energy Density } & \multicolumn{2}{|c|}{ Power Density } \\
\hline & & & & & $/ \mathrm{W} \mathrm{hr} \mathrm{kg-1}$ & $/ \mathrm{W} \mathrm{hr} \mathrm{L^{-1 }}$ & $/ \mathrm{kW} \mathrm{kg}^{-1}$ & $/ \mathbf{k W ~ L}^{-1}$ \\
\hline A123 & M1A & 39.8 & 17.0 & 794 & 83 & 193 & 2.5 & 5.7 \\
\hline LG & HB2 & 43.1 & 16.8 & 848 & 131 & 336 & 2.6 & 6.6 \\
\hline LG & HB4 & 43.1 & 16.7 & 778 & 132 & 342 & 2.6 & 6.7 \\
\hline LG & HG2 & 44.8 & 17.0 & 929 & 246 & 647 & 1.6 & 4.3 \\
\hline Samsung & $25 \mathrm{R}$ & 43.8 & 17.0 & 1036 & 216 & 556 & 1.7 & 4.3 \\
\hline Samsung & $30 \mathrm{Q}$ & 45.8 & 17.1 & 1032 & 245 & 657 & 1.2 & 3.2 \\
\hline Samsung & $48 \mathrm{G}$ & 67.4 & 24.8 & 989 & 263 & 717 & 0.5 & 1.4 \\
\hline Sony & VTC5A & 47.9 & 16.9 & 1024 & 196 & 552 & 2.3 & 6.5 \\
\hline Sony & VTC6 & 46.9 & 17.3 & 952 & 246 & 665 & 1.6 & 4.2 \\
\hline
\end{tabular}

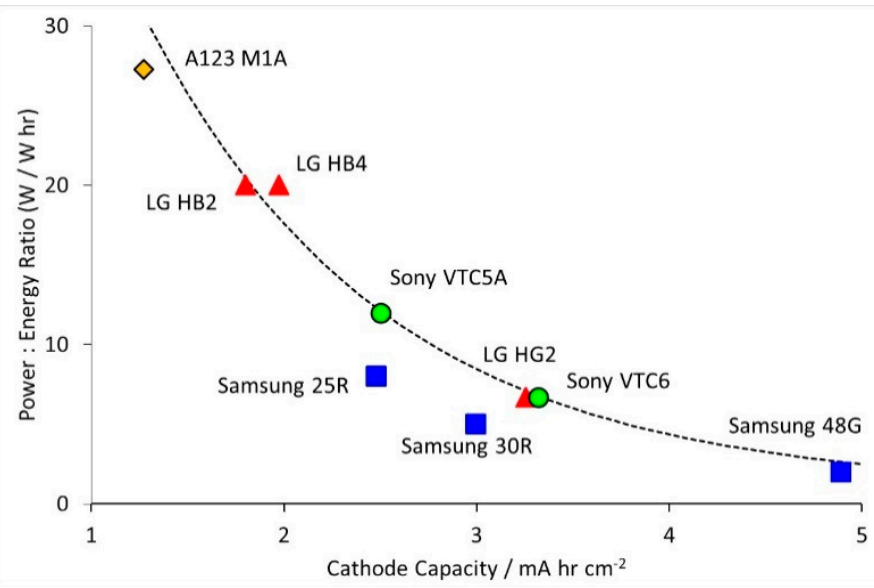

Figure 2. Correlation between power-energy ratios and areal capacities.

The thicknesses of five different components are plotted in Figure 3. The Samsung 48G cell had the thickest anode, giving the highest energy density and the lowest power density. The greatest surprise was the thickness of the A123 M1A cathode, since the cell had the highest power-energy ratio. This is likely to be due to the lower crystalline density of LFP $\left(3.6 \mathrm{~g} \mathrm{~cm}^{-3}\right.$ compared to $4.8 \mathrm{~g} \mathrm{~cm}^{-3}$ for NCA). For the current collectors and separator, the trend appeared to be largely historical. The available thicknesses of separators and battery grade copper and aluminium foil have reduced significantly in the last decade, due to improved manufacturing methods. Naturally, cell designers have taken advantage of these thinner materials, to increase energy density. The main exception was the two Sony cells, which both date back to 2015. The high power VTC5A cell had thicker copper and aluminium than the high energy VTC6 cell. Thicker current collectors will reduce the cell resistance, and improve heat transfer out of the cell, at the expense of energy density.

A similar difference was observed in the electrode tags; the cathode tag on the VTC5A was wider and thicker than the VTC6 tag. The two tag design options found in the cells are illustrated in Figure 4. Eight of the cells had full width tags welded to a patch in the coating, with tags at each end of the anode, and one cathode tag, offset from the centre. The one exception was the A123 M1A cell, which had two short tags welded to bare patches of metal. In practice, this could be achieved by selective scraping of the coating, or pre-positioning a patch to prevent the coating from adhering. A similar tag arrangement was observed in a commercial 26650 cell with an LFP cathode [15]. From a manufacturing perspective, it is simpler to coat continuously, rather than with a periodic full width patch ("skip" coating). This also avoids having to calendar thin sections of electrode, with just the exposed metal. Typically, the anode is larger than the cathode, to prevent over-charge at the cathode, and avoid forming lithium dendrites in regions of the anode with a high localised current density. It is interesting to note that in the A123 cell, there were regions of active cathode opposite bare copper foil on the anode. This may reflect the differences in over-charge behaviour between LFP and layered cathodes. 


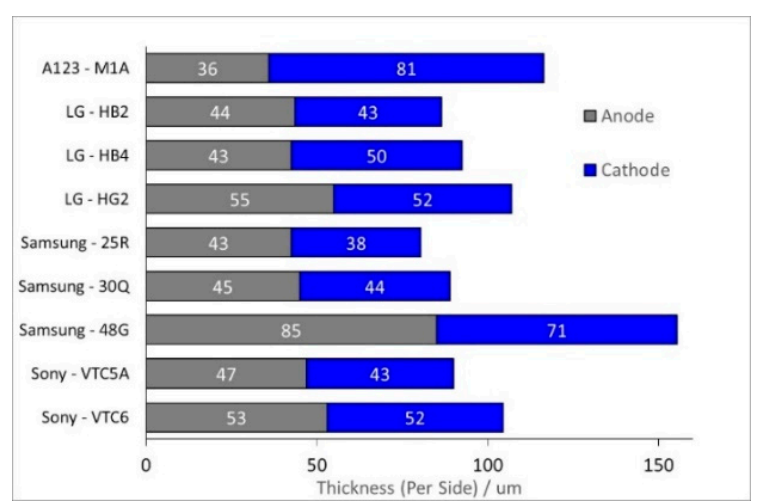

(a) Electrode coatings.

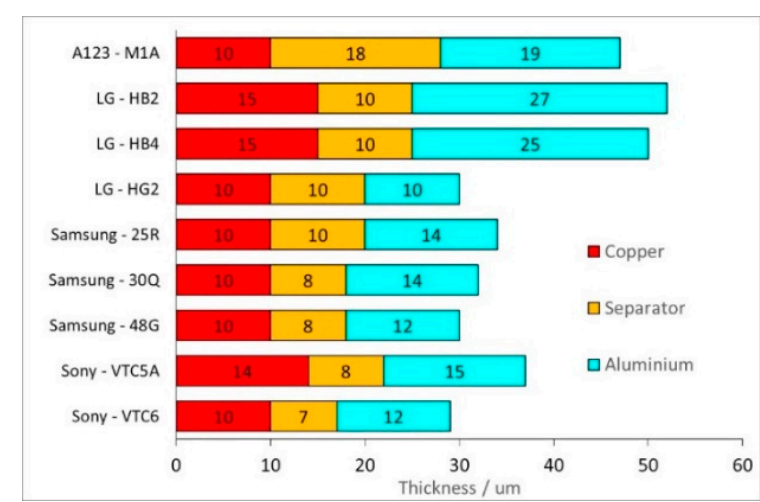

(b) Metal foils and separator.

Figure 3. Measured thicknesses for cell components.

A
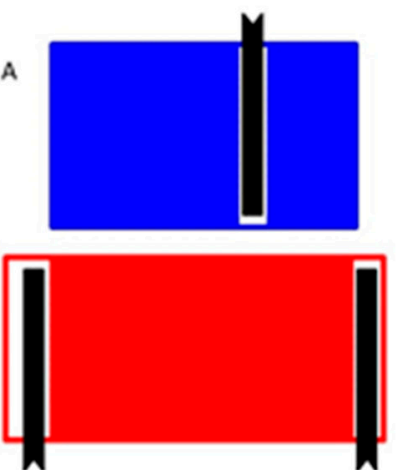

B
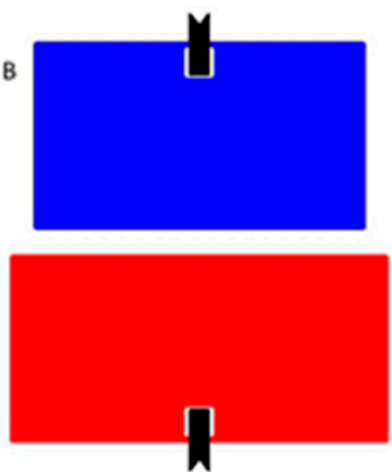

\section{Cathode}

\section{Anode}

Figure 4. Tag arrangements in cylindrical cells (A) Eight cells (B) 12318650 M1A.

The reason that the cathode was offset in the other eight cells shows the importance of thermal management in cell design. From an electrical perspective, a symmetrical cathode tag gives the minimum resistance. However, because of the spiral winding pattern, a symmetrical cathode tag is relatively close to the can wall. Using an offset tag places the tag roughly half way across the winding, maximising the heat flow out through the tag. There was an expectation that high power cells would use more tags then high energy cells, to reduce the cell resistance and improve heat transfer. Clearly, the twin anode tag is a net benefit, even in cells optimised for high energy. Many cylindrical super-capacitors use edge connections rather than discrete tags [16], but this approach is not considered necessary in the high power cells.

The actual electrode formulations are not known, and difficult to measure. They can be analysed through a systematic chemical extraction procedure, but in initial tests, the measurement errors were too high to give accurate compositions. However, by making educated assumptions based on known electrode compositions and patent applications, it is possible to calculate the capacities of the active materials, and the electrode porosities. Figure 5 shows the values obtained, assuming an anode formulation of active-binder-carbon $=$ 95:4:1 (wt \%), and a cathode formulation of 96:2:2 (wt \%). The one exception was the M1A cathode, which used a 79:11:10 formulation, based on A123 patents published at the time the cell was being designed [17]. Several of the anode values were higher than the theoretical capacity of graphite i.e., $372 \mathrm{~mA} \mathrm{hr} \mathrm{g}^{-1}$. This suggests that the electrodes contained a higher capacity component like silicon. The cathodes showed the historical trend to higher capacities, generally by using a higher nickel content. 

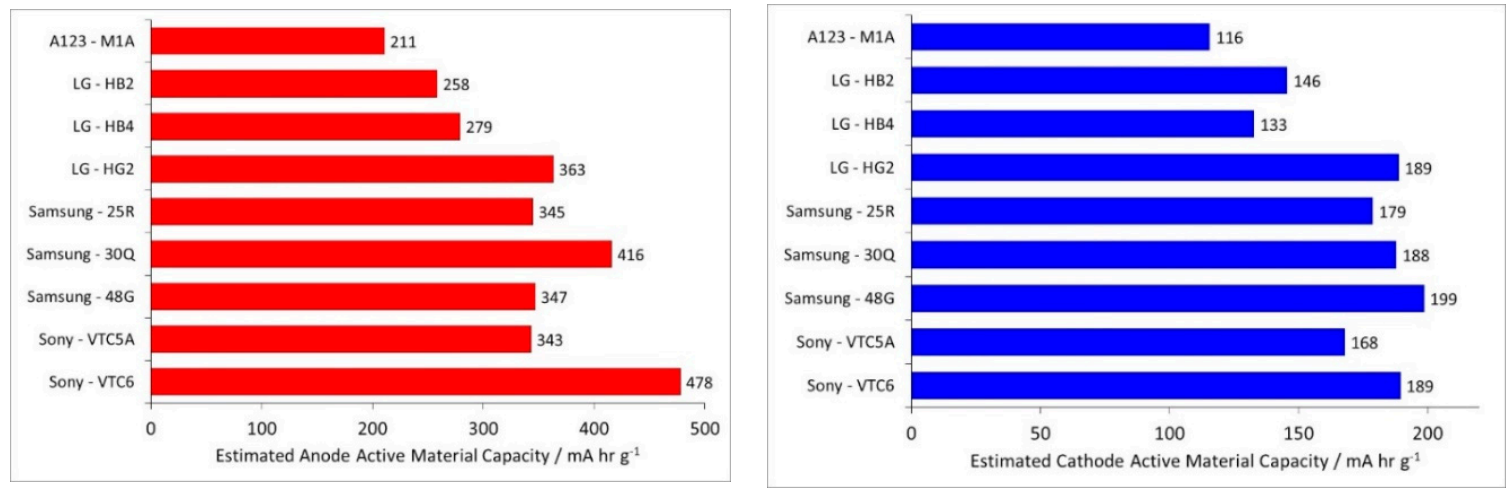

Figure 5. Estimated capacities for anode and cathode active materials.

The average porosity in an electrode can be calculated from the coat weight, the coating thickness and the average density of the coating components [18]. This density is relatively insensitive to the electrode formulation. Porosity values for the anodes and cathodes are plotted in Figure 6 . The anode porosity values were pretty similar, apart from the VTC6 cell. This was surprising, since the VTC6 is an energy rather than power cell. The cathode porosities showed much more variation. The three cells with the highest power-energy ratios (M1A, HB2 and HB4) had higher porosities than the other six cells.
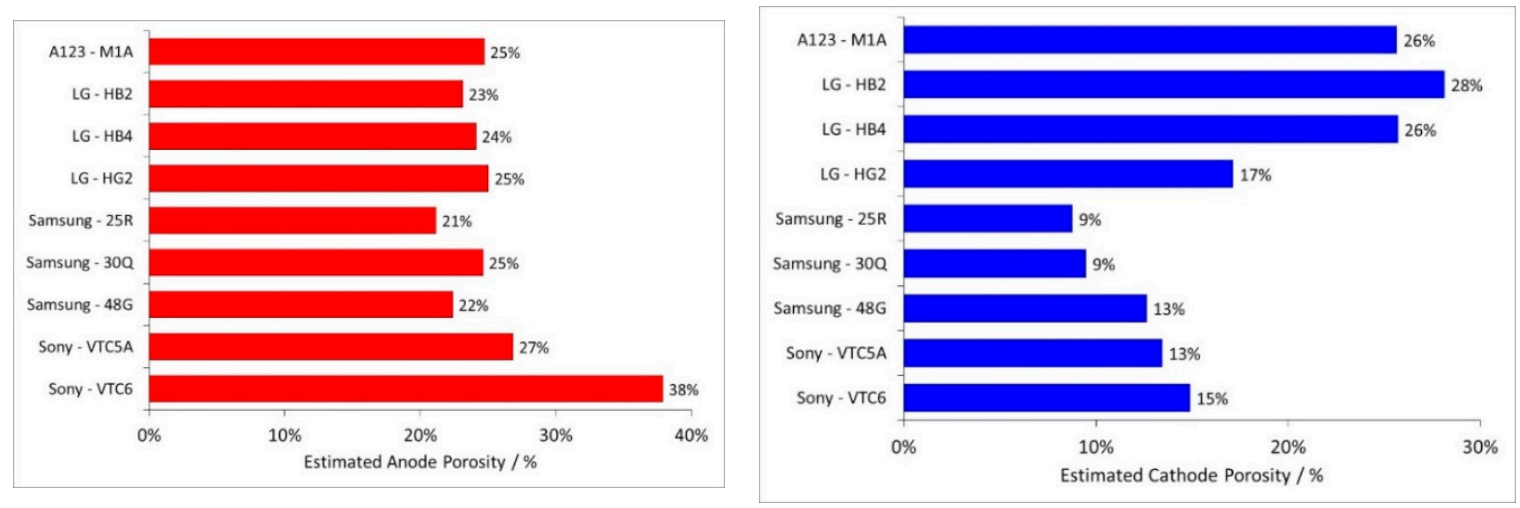

Figure 6. Calculated porosity values for anode and cathode coatings.

The cathode porosities were also reflected in the electrolyte weights, shown in Figure 7. These were calculated from the difference between the initial cell weights, and the weights of the other components, after washing and drying. Historically, a value of around $3 \mathrm{~g}$ of electrolyte per $\mathrm{A} \mathrm{hr}$ was considered reasonable. The electrolyte should fill all the pores in the electrodes and separator, but still leave some void space within the cell for the collection of SEI gases. With thinner separators, and lower porosity cathodes, it has clearly been possible to reduce the value to less than $2 \mathrm{~g}(\mathrm{~A} \mathrm{hr})^{-1}$ in many of the cells. However, the thick and relatively porous LFP cathode in the A123 cell still requires a higher quantity of electrolyte.

To obtain further information, it is necessary to use spectroscopic techniques like scanning electron microscopy (SEM), coupled with energy dispersive x-ray spectroscopy (EDS). Representative images for the nine anodes and cathodes are shown in the Figures 8 and 9, respectively. Amongst the anodes, eight out of nine seemed quite similar, the exception being the A123 M1A cell. In this cell, the carbon particles appeared to be flakes or shards, rather than the more rounded particles seen in the other cells. Apart from the HB2 and HB4 cells, there was a mixture of smaller and larger particles, to maximise the tap density and optimise use of the available volume. The cathodes also appeared similar, with a mixture of smaller and larger particles. The latter are secondary particles, agglomerates of much smaller primary particles. This approach minimises the diffusion path lengths, while maximising the 
tap density of the material. The cathodes appeared to be heavily calendared, and some secondary particles were beginning to break apart into primary particles.

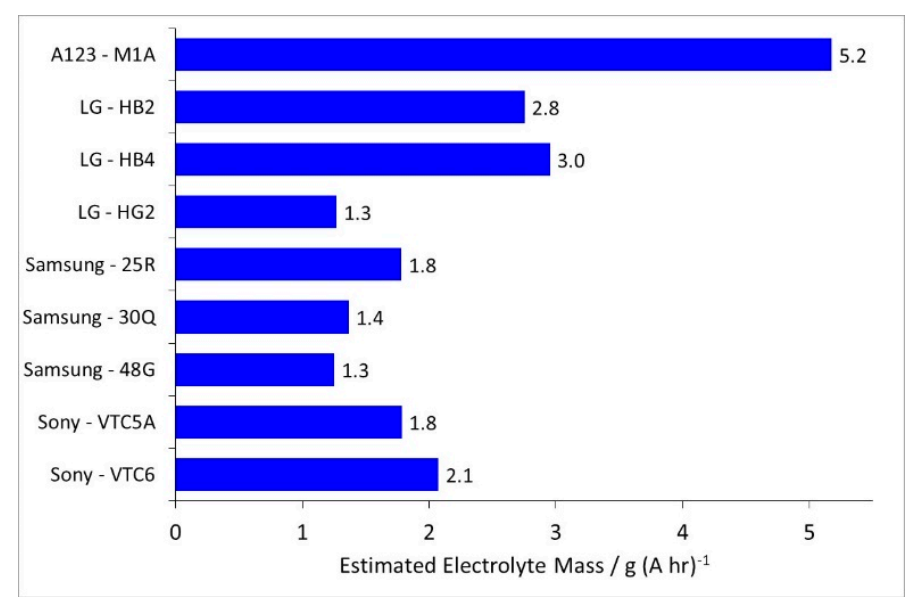

Figure 7. Estimated quantity of electrolyte used in cells.
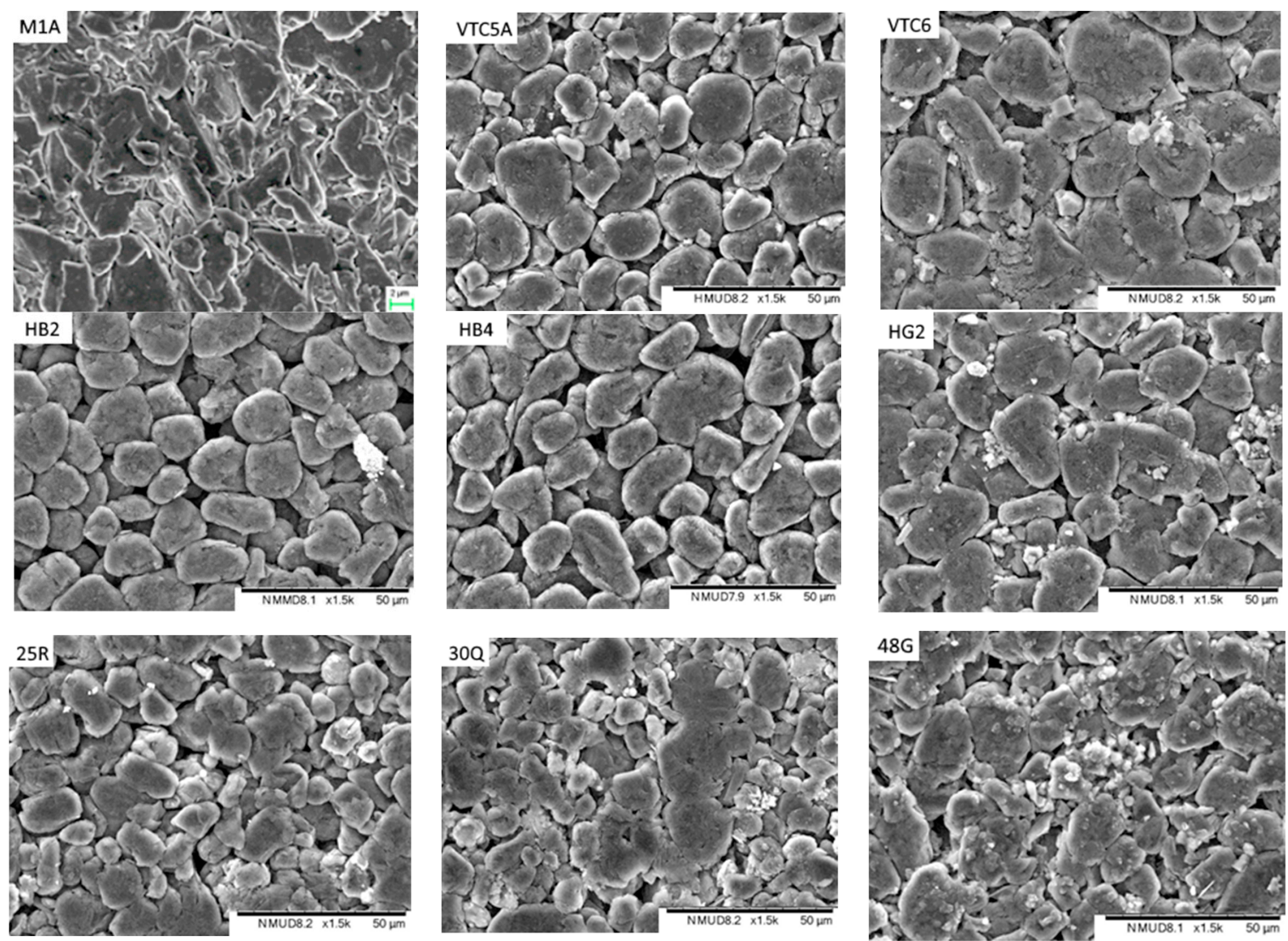

Figure 8. SEM images of anode coatings. 

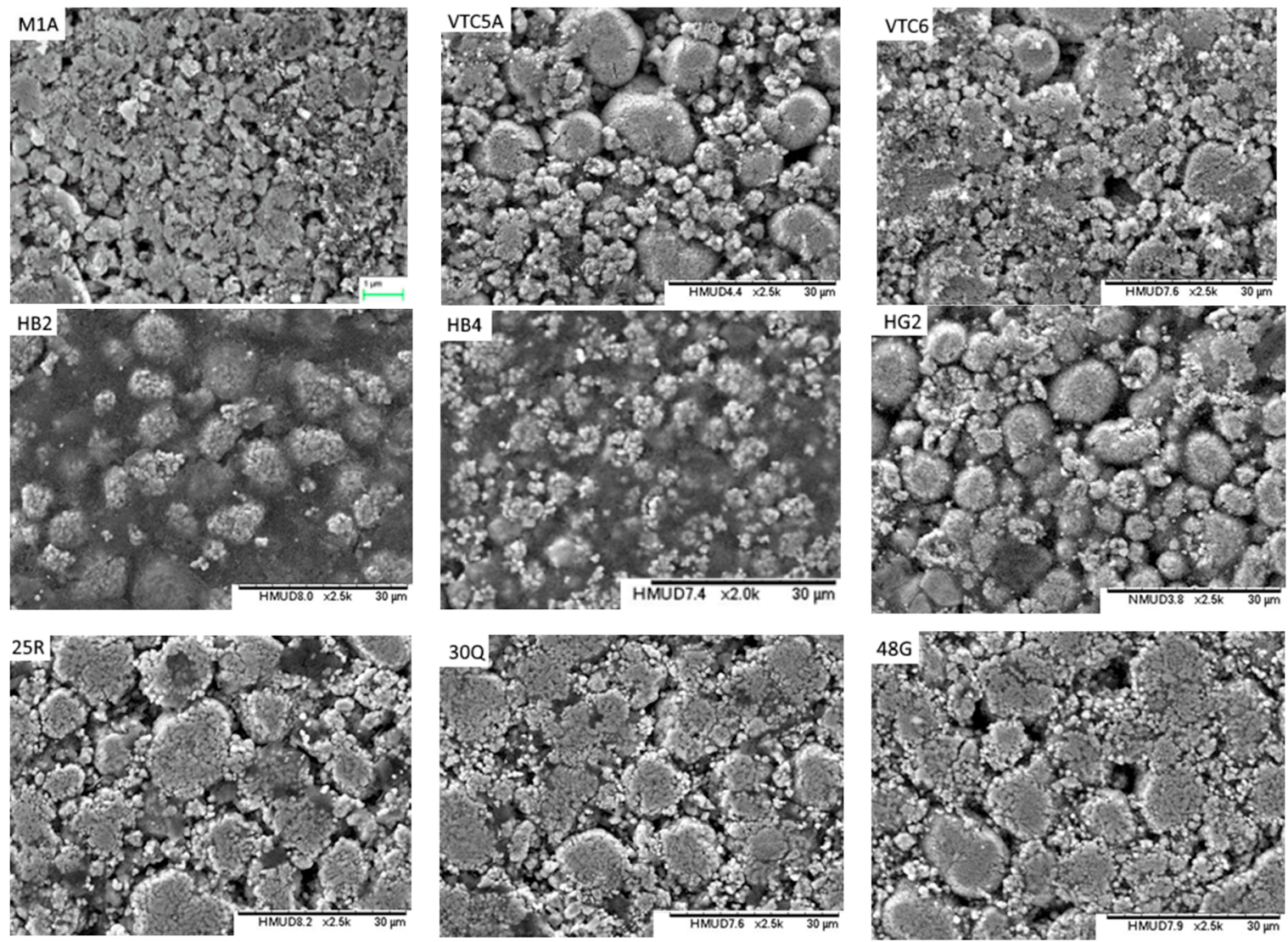

Figure 9. SEM images of cathode coatings.

EDS maps of the anodes and cathodes are presented in the Supplementary Materials. The conclusions from the EDS measurements are collected in Table 5. Six of the nine anodes contained silicon, splitting on historical lines i.e., designed before or after 2012. The silicon was found in localised particles, typical of a "sprinkling" strategy. In the EDS maps, the silicon was usually associated with oxygen. Silicon monoxide $\left(\mathrm{SiO}_{\mathrm{x}}\right)$ is a commonly used silicon material [19], but actually contains regions of silicon and $\mathrm{SiO}_{2}$ [20]. During the formation cycle, the $\mathrm{SiO}_{2}$ is are converted irreversibly to lithium oxide and lithium silicates [20], while the silicon itself is reversibly intercalated and de-intercalated. The lithium oxide will react with any trace HF in the electrolyte, but the silicates will probably remain in position. Therefore, the presence of silicon and oxygen together suggests that the original material was $\mathrm{SiO}_{\mathrm{x}}$. If the oxygen was part of a different (thicker) SEI layer on the silicon, then fluorine would also be expected on these particles.

Table 5. Active materials identified by energy dispersive x-ray spectroscopy (EDS).

\begin{tabular}{cccc}
\hline Manufacturer & Model & Anode & Cathode \\
\hline A123 & M1A & Graphite & LiFePO $_{4}$ \\
LG & HB2 & Graphite & NMC-532 \\
LG & HB4 & Graphite & NMC-111 \\
LG & HG2 & Graphite + Si & NMC-811 \\
Samsung & $25 R$ & Graphite + Si & NCA \& NMC-622 \\
Samsung & 30Q & Graphite + Si & NCA \\
Samsung & 48G & Graphite + Si & NCA \\
Sony & VTC5A & Graphite + Si & NCA \\
Sony & VTC6 & Graphite + Si & NCA \\
\hline
\end{tabular}


There was more variation between the cathode materials. At this stage, the compositions are indicative, rather than absolute. The HG2 cell contained a nickel rich NMC. The measurements suggested 811 rather than 622, though this would be an early introduction for a cell designed in 2014 . The NCA in the Sony VTC5A cell looked to be the "standard" formulation $\mathrm{LiNi}_{0.80} \mathrm{Co}_{0.15} \mathrm{Al}_{0.05} \mathrm{O}_{2}$. However, the NCA in two of the Samsung cells appeared to be a nickel rich version i.e., $\mathrm{LiNi}_{0.80+\delta} \mathrm{Co}_{0.15} \mathrm{Al}_{0.05-\delta} \mathrm{O}_{2}$ with $\delta \sim 0.04$ [21].

The NCA in the Sony VTC6 cell appeared to have a surface coating of aluminium oxide. This made it difficult to estimate the actual particle composition, but the Ni:Co ratio appeared to be higher than in the VTC5A cell. Surface coating of cathode particles has been proposed as a method to increase the charging voltage limit, and hence the capacity of the material [22]. The real surprise was the Samsung 25R cathode. Visually, all the particles looked the same, but some contained no manganese. The use of a mixed NCA/NMC cathode has been proposed [23], to experience some of the benefits of both materials.

From the SEM images, it was possible to estimate the particle size of the active materials. For the cathodes, this was the size of the secondary particles, rather than the primary particles. Figure 10 plots typical values of the particle size against the power-energy ratio. The results showed the expected trend of smaller particle sizes for higher power.

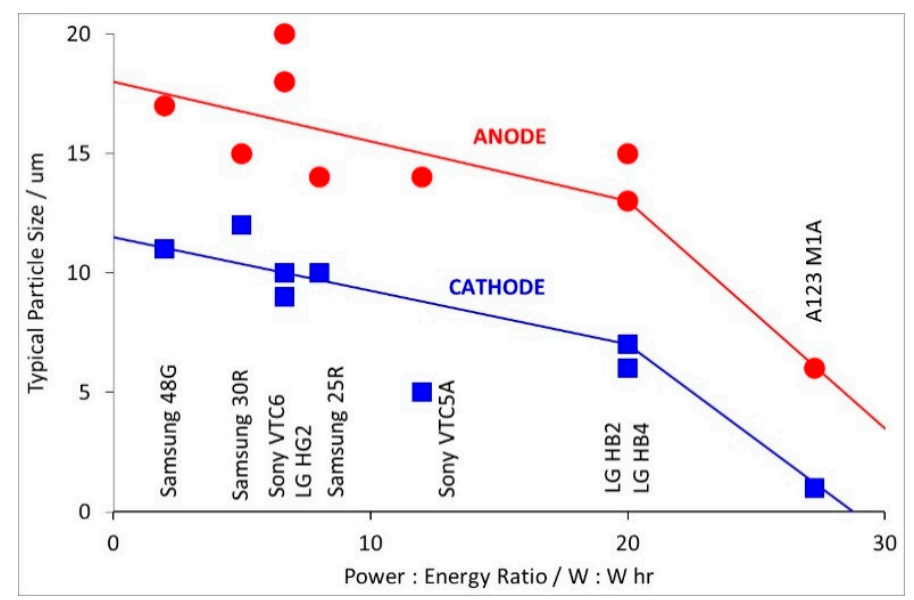

Figure 10. Correlation between active material particle sizes and power-energy ratios.

\section{Discussion}

Nine commercial lithium ion cells have been disassembled, and the differences between high energy density and high power density cells investigated. Some design features were in line with expectations, but others were not:

- Electrodes. Higher power density is achieved by using lower coat weights, lower areal capacities, smaller active particles and higher cathode porosities. All the electrodes appeared to be heavily calendared.

- Tag Configuration. It was expected that high power cells would use more tags, but eight out of nine cells used the same three tag configuration. The exception was the high power A123 M1A cell, which had just two symmetrically located tags.

- Separators. Thinner separators benefit both energy density and power density. Manufacturers have been reducing the thickness of their separators, while still maintaining safety. The separators selected seem to be the best available at the time the cell was designed.

- Current Collectors. The thicknesses did not follow any design trend, but were also related to the availability of components at the point of design. However, the high power Sony VTC5A cell had thicker current collectors and tags than the high energy Sony VTC6 cell, despite being designed in the same year. 
In summary, this work gives an insight into the limitations of cell and electrode design for high power lithium ion cells. High power density requires the minimisation of every component of the overall cell resistance, based on lower electrode coat weights, thinner separators with lower tortuosity and thicker tags and current collectors. The electrode resistances and lithium ion diffusion path lengths can be reduced by using smaller particle sizes for the active materials, and higher loadings of conductive additives.

For all these cells, the maximum charge rate in the cell specification sheet was much lower than the maximum rate of discharge. Further work to understand the true electrochemical limitations of these electrodes is underway, to give more insight into limitations for high power beyond cell design, which was the focus of this study.

\section{Materials and Methods}

Upon receipt, the cells were subjected to a simple charge-discharge cycle, to leave them in a fully discharged state. The discharge capacities and cell weights were used to confirm that the cells were genuine, as there are some counterfeit cells in the e-cigarette market. The cycles were at $\pm C / 10$, with the cell capacities and voltage limits taken from the manufacturers' datasheets. The average discharge voltage was calculated by dividing the discharge energy ( $\mathrm{W}$ hr) by the discharge capacity (A hr). This voltage was then multiplied by the maximum continuous discharge current rating, to give the cell power.

After dimensional measurements, the cells were transferred to an argon filled glove box, for disassembly. The top cap was cut open using the groove below the sealing gasket, and the positive tag was then cut. After allowing the volatile components of the electrolyte to evaporate overnight, the can base was cut, enabling the coil to be pushed out of the can. The 18650 cells were cut using a special lathe from MTI. The 21700 cell used a pipe cutter, and then can peeling with pliers. If the coil could not be pushed out of the can, then the can peeling approach was also used. The cell coils were unwound, and the extent of electrode delamination (if any) was observed. The electrodes and separator were weighed and measured, and then immersed in anhydrous dimethyl carbonate (DMC) overnight. This removed the residual electrolyte components, before a second weighing. Pieces of electrode and separator were posted out of the glove box as required, for thickness measurements and examination by SEM.

Supplementary Materials: The following are available online at http://www.mdpi.com/2313-0105/5/4/64/s1, containing Figures S1-S11 and Tables S1-S3.

Author Contributions: Conceptualisation, M.J.L. and E.K.; methodology, M.J.L.; investigation, M.J.L. and J.B.; writing—original draft preparation, M.J.L.; writing—review and editing, M.J.L. and E.K.; supervision, E.K.

Funding: This work was undertaken as part of a contract with the Advanced Propulsion Centre (www.apcuk.co.uk). WMG gratefully acknowledge this funding from APC.

Conflicts of Interest: The authors declare no conflict of interest.

\section{References}

1. Chu, A.; Braatz, P. Comparison of commercial super-capacitors and high power lithium ion batteries for power assist applications in hybrid electric vehicles I. Initial characterization. J. Power Sources 2002, 112, 236-246. [CrossRef]

2. Burke, A.; Miller, M. The power capability of ultra-capacitors and lithium batteries for electric and hybrid vehicle applications. J. Power Sources 2011, 196, 514-522. [CrossRef]

3. Quinn, J.B.; Waldmann, T.; Richter, K.; Kasper, M.; Wohlfahrt-Mehrens, M. Energy density of cylindrical lithium in cells: A comparison of commercial 18650 to 21700 cells. J. Electrochem. Soc. 2018, 165, 3284-3291. [CrossRef]

4. Gallagher, K.G.; Nelson, P.A.; Dees, D.W. Simplified calculation of the area specific impedance for battery design. J. Power Sources 2011, 196, 2289-2297. [CrossRef] 
5. Zheng, H.; Li, J.; Song, X.; Liu, G.; Battaglia, V.S. A comprehensive understanding of electrode thickness effects on the electrochemical performance of lithium ion battery cathodes. Electrochim. Acta 2012, 71, 258-265. [CrossRef]

6. Datasheet. High Power Lithium Ion APR18650M1A. 2009. Available online: https://www.batteryspace.com/ prod-specs/6612.pdf (accessed on 25 September 2019).

7. Datasheet. Technical Information of LG18650HB2 (1.5 Ah). 2011. Available online: https://telit.co.rs/ PDFDokumenti/Li-Ion/LG18650HB2.pdf (accessed on 25 September 2019).

8. Datasheet. Product Specification of ICR18650HB4 (1.5 Ahr). 2011. Available online: http://queenbattery. com.cn/our-products/187-lg-hb2-inr18650hb2-186501500mah-10a-37v-li-ion-battery-cell.html (accessed on 25 September 2019).

9. Datasheet. Technical Information of LG18650HG2 (3.0 Ah). 2014. Available online: http://enerpower.de/wp/ wp-content/uploads/2016/03/Specification_LGC_18650HG2.pdf (accessed on 25 September 2019).

10. Datasheet. Introduction of INR18650-25R. 2013. Available online: https://www.powerstream.com/p/ INR18650-25R-datasheet.pdf (accessed on 25 September 2019).

11. Datasheet. Introduction of INR18650-30Q. 2014. Available online: http://enerpower.de/wp/wp-content/ uploads/2016/03/Technical_Information_INR18650-30Q.pdf (accessed on 25 September 2019).

12. Datasheet. Tentative Product Specification for INR21700-48G. 2015. Available online: https://www. imrbatteries.com/content/samsung_48G.pdf (accessed on 25 September 2019).

13. Datasheet. Technical Information for US18650VTC5A. 2015. Available online: http://enerpower.de/wp/wpcontent/uploads/2016/04/Specification-US18650VTC5A.pdf (accessed on 25 September 2019).

14. Datasheet. Technical Information for US18650VTC6. 2015. Available online: http://enerpower.de/wp/wpcontent/uploads/2016/10/Specification-US18650VTC6.pdf (accessed on 25 September 2019).

15. Petzl, M.; Danzer, M.A. Non-destructive detection, characterisation and quantification of lithium plating in commercial lithium ion cells. J. Power Sources 2014, 254, 80-87. [CrossRef]

16. Khakhalev, A.D. Collector Plate for Energy Storage Device and Methods of Manufacturing. U.S. Patent 9,805,877, 31 October 2017.

17. Chiang, Y.-M.; Chu, A.C.; Jang, Y.-I.; Meethong, N.; Kao, Y.-H.; Riley, G.N.; Pullen, A.E.; Thomas-Alyea, K.E. Multi-Functional Mixed Metal Olivines for Lithium Ion Batteries. U.S. Patent 9,509,019, 29 November 2016.

18. Landesfeind, J.; Hattendorff, J.; Ehrl, A.; Wall, W.A.; Gasteiger, H.A. Tortuosity determination of battery electrodes and separators by impedance spectroscopy. J. Electrochem. Soc. 2016, 163, A1373-A1387. [CrossRef]

19. Lee, S.-M.; Jeong, G.-J.; Kim, S.-S.; Nitta, W. Negative Active Materials for a Rechargeable Lithium Battery, a Method of Preparing the Same, and a Rechargeable Lithium Battery Comprising the Same. U.S. Patent 9,012,082, 21 April 2015.

20. Kim, K.W.; Park, H.; Lee, J.G.; Kim, J.; Kim, Y.-U.; Ryu, J.H.; Kim, J.J.; Oh, S.M. Capacity variation of carbon coated silicon monoxide negative electrode for lithium ion batteries. Electrochim. Acta 2013, 103, 226-230. [CrossRef]

21. Song, Y.-M.; Hong, M.-Z.; Kim, J.-H.; Park, D.-H.; Kim, M.-H.; Moon, J.-H.; Park, H.-E.; Kim, K.-H.; Kim, D.-J.; Choi, J.-J.; et al. Composite Cathode Active Material, Lithium Battery Including the Same, and Method of Preparing the Same. U.S. Patent 9,991,511, 5 June 2018.

22. Kim, Y.; Kim, H.S.; Martin, S.W. Synthesis and electrochemical characteristics of $\mathrm{Al}_{2} \mathrm{O}_{3}$ coated NCM cathode materials for lithium ion batteries. Electrochim. Acta 2006, 52, 1316-1322. [CrossRef]

23. Yang, C.-M.; Masahiro, K.; Kim, S.-H. Positive Active Materials and Positive Electrode for Rechargeable Lithium Battery, and Rechargeable Lithium Battery Including the Positive Electrode. U.S. Patent 8,703,339, 22 April 2014.

(C) 2019 by the authors. Licensee MDPI, Basel, Switzerland. This article is an open access article distributed under the terms and conditions of the Creative Commons Attribution (CC BY) license (http://creativecommons.org/licenses/by/4.0/). 